\title{
The characteristics of respiratory ill health of wool textile workers
}

\author{
R G Love, M Muirhead, H P R Collins, C A Soutar
}

\section{Abstract}

The relations of lung function and chest radiographic appearances with exposure to inspirable dust were examined in 634 workers in five wool textile mills in west Yorkshire, randomly selected to represent fully the range of current exposures to wool mill dust. Most of these workers could be categorised into three large sex and ethnic groups; European men, Asian men, and Asian women. Exposures to inspirable dust had been measured at a previous survey and time spent in current job, and in the industry were used as surrogates for lifetime cumulative exposures. Chest radiographs were interpreted on the International Labour Office (ILO) scale by three medically qualified readers, and the results combined. Profusions of small opacities of $0 / 1$ on the ILO scale, or greater, were present in only $6 \%$ of the population, and were not positively associated with current exposure to wool mill dust, or duration of exposure. In general, statistically significant relations between exposure and lung function indices were not found, with the exception of an inverse relation between the forced expiratory volume/forced vital capacity ratio and dust concentration in European women. A suggestive but not statistically significant inverse relation between FVC and current dust concentration was seen in Asian men. Substantial differences were found between mills in mean values of lung function variables after adjustment for other factors but these were not apparently related to the differences in dust concentrations between these mills. Dyeworkers and wool scourers (mostly European men in relatively dust free jobs) on average experienced an FEV $251 \mathrm{ml}$ lower than other workers when age, height, smoking habits, and occupational factors had been taken into account. Twenty four

Institute of Occupational Medicine, 8 Roxburgh Place, Edinburgh, EH8 9SU

R G Love, M Muirhead, H P R Collins, C A Soutar per cent of the workforce responded to intracutaneous application of one or more common allergens (weal diameter at least 4 $\mathrm{mm}$ ), only $12(7.9 \%)$ of these responding to wool extracts. Atopic subjects did not appear to have an increased susceptibility to the effects of inspirable wool dust on lung function. These studies suggest that exposure to wool mill dust may cause functional impairment in some workers but there is little indication from these data of frequent or severe dust related functional deficits. More detailed estimates of cumulative dust exposure by reconstruction of exposure histories might clarify associations between exposure to dust and lung function. The chest radiographic findings provide no evidence that exposure to wool mill dust is related to lung fibrosis.

Previous studies of wool textile workers reported by ourselves $^{1}$ and by others ${ }^{2-6}$ have indicated that respiratory symptoms are more prevalent in those workers exposed to airborne wool dust than in those who are not. Only Zuskin $e t a l^{6}$ and more recently Özesmi et $a l^{7}$ have reported the results of lung function tests in wool textile workers. Zuskin et al noted that $\dot{\mathrm{V}}_{\max 50}$ (an indicator of airflow obstruction) fell significantly among carders and spinners during a work shift and also that those with more than 10 years of exposure had a significantly lower preshift $\dot{\mathrm{V}}_{\max 50}$. A study of Turkish carpet weavers showed that reduction in maximum mid-expiratory flow (MMF, another similar indicator) was significantly related to the number of years of exposure ${ }^{7}$ but it was not clear whether allowance had been made for age. Also, these workers found that MMF was reduced compared with a control group after four hours of work on Monday but not on Tuesday. The presence of high airborne dust concentrations and bacterial endotoxin contamination of the dusts led these authors to conclude that a byssinotic condition, indistinguishable from that found in cotton workers, was present.

Our study of west Yorkshire wool textile workers ${ }^{8}$ showed that high exposures existed (greater than 10 
$\mathrm{mg} \mathrm{m}^{-3}$ inspirable dust, some much greater) in some jobs in the industry and that frequencies of symptoms of chronic bronchitis, wheeze, breathlessness, rhinitis, and conjunctivitis were associated with current exposure.

We have now carried out a cross sectional epidemiological study to determine the relations between lung functional and chest radiographic abnormalities and exposure to wool textile mill dusts and to ascertain the relation of atopy with dust concentration, job characteristics, symptoms, and abnormality of lung function.

\section{Methods}

The effects of wool dust on lung function and radiographs have been examined in a sample of the 2151 workers from 15 mills studied previously. ${ }^{1}$ Five mills were selected because some of the occupational groups represented in them were associated with average exposures to inspirable dust which were at the higher end of the range.

Four of the five selected mills were carpet yarn mills (Nos 11, 13, 14, and 15) and the other (No 4) produced worsted "tops" (balls of combed wool). At the previous survey 103,292, 230,222, and 257 employees respectively had taken part at these mills. A study group of 748 subjects was selected by stratified random sampling; about half from the high exposure occupational groups and half from other occupational groups. Eighty three, 151, 213, 102, and 199 employees in these groups were invited to participate at mills $11,13,14,15$, and 4 respectively.

The following measurements were carried out in two mobile laboratories sited at each mill: (1) full size chest $x$ ray film; (2) skin prick tests using common allergens and wool extracts; (3) lung function including forced expiratory manoeuvres and carbon monoxide single breath transfer factor. Most staff were seen during normal working hours (9.00 am-5.00 pm) and permanent night shift workers during the early part of their shift $(7.00 \mathrm{pm}-$ midnight). Personal information included name, date of birth, occupation, and smoking habit.

\section{LUNG FUNCTION TESTS}

\section{Spirometry}

Three technically satisfactory forced expiratory manoeuvres were performed, if possible, by each subject into a Morgan M8 dry rolling seal spirometer (PK Morgan, Chatham). The volume signal was passed through a flow volume differentiator and the volume and flow signals were displayed in real time on a fast response $\mathrm{XY}$ recorder (Rikadenki RW 201-T) and through a microprocessor to allow selected indices to be calculated and printed out immediately. Forced expiratory volume in one second $\left(\mathrm{FEV}_{1}\right)$ and forced vital capacity $(\mathrm{FVC})$ were recorded. Peak expiratory flow (PEF), maximum expiratory flow at $50 \%$ and $25 \%$ of remaining vital capacity $\left(\dot{\mathrm{V}}_{\max 50}\right.$ and $\left.\dot{\mathrm{V}}_{\max 25}\right)$, forced expiratory time, and mean transit time were also recorded in this way, but were not reported in this study. The $\mathrm{FEV}_{1} / \mathrm{FVC}$ ratio was derived subsequently. Up to six attempts were allowed in which to achieve three acceptable forced expiratory manoeuvres. If only one or two attempts were satisfactory, these were recorded. The best flow volume curve was selected for analysis on the basis of technical correctness, a clearly maximum effort (peaked not rounded peak flow point), largest FVC, and largest FEV if more than one curve had the same maximum FVC.

\section{Transfer factor}

Duplicate measurements (three if necessary) of single breath carbon monoxide transfer factor were made using an automated spirometer system (Morgan TTB) according to the method of Meade et al. ${ }^{9}$ The average of two technically satisfactory efforts was used for analysis of transfer factor (TLCO), alveolar volume (VA) and the transfer coefficient $\mathrm{KCO}=\mathrm{Tlco} / \mathrm{VA}$. Height and weight were also recorded in a standard manner.

\section{CHEST RADIOGRAPHY}

Full size postero-anterior radiographs were taken and any abnormalities reported. Subsequently these films were batched randomly into four groups and read for epidemiological purposes by three doctors (courtesy of British Coal Radiological Services) and five non-medically qualified members of a trained film reading panel. ${ }^{10}$ Each reader classified the films according to the International Labour Office classification of radiographs of pneumoconiosis ${ }^{11}$ and noted any other abnormalities. Results based on the doctors' classifications only are reported here. A combined score of profusion of small opacities was used to classify each radiograph, based on the mode of the readings of the medical panel (classified as either " $0 / 0$ " or " $0 / 1$ or greater"). Small opacities were classified as rounded or irregular according to that reader's opinion of predominant shape. A majority verdict was used to give a combined classification of rounded or irregular small opacities, which were classified as ambiguous in shape if, for example, one reader recorded rounded, another irregular, and the third $0 / 0$ profusion.

\section{SKIN PRICK TESTS}

Intracutaneous prick test solutions to common allergens (house dust, house dust mite ( $D$ pteronyssinus), grass pollens, sheep wool (untreated) and white wool (treated) as well as a control solution) were obtained from Bencard. A drop of each (coded) solution was applied to the flexor surface of the forearm in a predetermined order by one person in one 
laboratory. A disposable sterile HMB Allergogen needle (HMB Medical Concepts Ltd) was pressed through each drop onto the skin and excess solution was removed. After 15 minutes the weal diameter (if present) was measured by a second operator "blind" in the other laboratory to the nearest millimetre by means of a special gauge (Bencard) and recorded.

Atopy was defined as the presence of a weal to any allergenic solution of $4 \mathrm{~mm}$ or greater in diameter, as long as the control solution did not produce a weal of $1 \mathrm{~mm}$ or greater. No reactions to any solution or reactions to all solutions including the control were classified as negative.

\section{DUST EXPOSURES}

Dust sampling methods have been described in detail elsewhere. ${ }^{8}$ Briefly, personal inspirable dust samplers were worn by representative workers of different processes within each mill for several hours during a shift, until sufficient samples had been collected to characterise the current dust concentrations experienced by the workforce of each mill. Detailed occupational histories were also obtained from all workers. Jobs in each mill, where similar dust concentrations and processes occurred, were combined to form 16 occupational groups, to which average inspirable concentrations were assigned, based on the measurements made at the mill concerned. These represented current exposure to inspirable dust. Because it was considered unrealistic to estimate employees' lifetime cumulative dust exposures without further investigations, cumulative exposure to dust in the current job only was explored as a further index of exposure (most workers had spent their time in the industry in either the current or the current plus one other job).

\section{DATA ANALYSIS}

Cross tabulations were constructed to examine the level of agreement within and between the medical and the non-medical panels in the classification of chest radiographs; the prevalence of small opacities according to independent factors, such as age, smoking habit, mill, etc, was also examined using cross tabulations. Graphs and tables were used to display any apparent relation between indices of lung function and occupational and non-occupational factors. The BMDP package ${ }^{12}$ was used for formal investigation of these relations using standard multiple regression methods. Factors were generally entered in the order: age, height, weight, smoking, age-smoking interaction, mill, and log dust concentration and were included irrespective of statistical significance. Numbers of hours worked a week, time in the industry, and cumulative exposure to dust in the current job were also investigated where appropriate.

\section{Results}

CHARACTERISTICS OF THE STUDY POPULATION

Six hundred and thirty four subjects attended for survey, representing $89 \%$ of those sampled who were still employed at the mill at the time of survey. Thirty refused to take part and the remainder were ill or otherwise unavailable. Language and technical difficulties with the lung function tests reduced the numbers with complete data. Six hundred and twenty six had chest radiographs taken. Eight of the women were either thought to be pregnant, or had had a recent (chest) radiograph and did not have radiographs taken.

The average age of those examined was 41.6 years, $75.4 \%$ were men and $24.6 \%$ were women; $68.0 \%$ were European, $28.5 \%$ were of Asian and $3.5 \%$ were of West Indian origin. Overall $52.1 \%$ were current smokers, $31.4 \%$ non-smokers, and $16.6 \%$ ex-smokers. Figure 1 shows the distribution of inspirable dust concentrations to which these workers were exposed. The European women tended to be exposed to dust concentrations at either the low or the high parts of the range but this was not sufficiently pronounced for separate high and low exposure groups to be formed for analysis.

\section{CHEST RADIOGRAPHIC ABNORMALITIES}

The radiographs of 626 men and women were classified. Most films were classified by each reader as category $0 / 0$, the proportion of radiographs classified by different readers as showing category

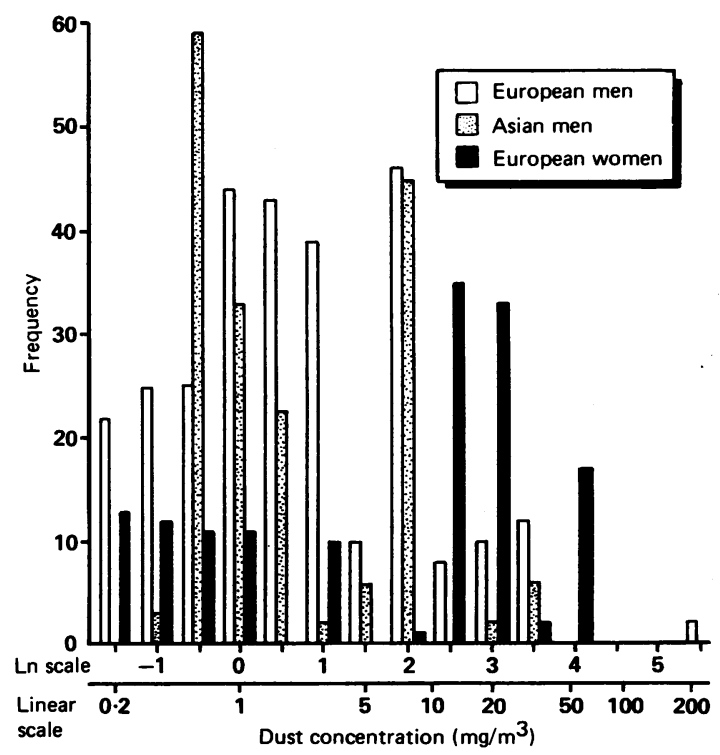

Figure 1 Distribution of inspirable dust concentrations in current job (log scale) for European men $(n=286)$ and women $(n=145)$ and Asian men $(n=179)$. 


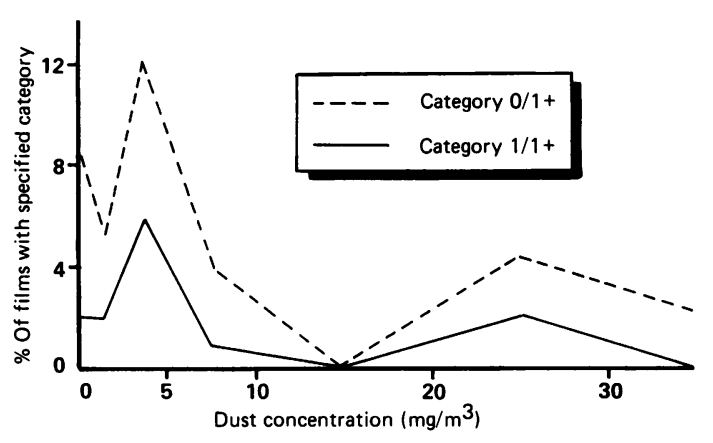

Figure 2 Percentages of films classified as category $0 / 1+$ and category $1 / 1+($ majority score verdict) in relation to dust concentration in present job.

$0 / 1$ or more ranging from $5 \%$ to $11 \%$. The readers classified $2 \cdot 2 \%, 3 \cdot 0 \%$ and $1 \cdot 1 \%$ of the films as category $1 / 1$ or more. Agreement on the 12 point ILO scale between pairs of medical readers ranged from $87 \%$ to $91 \%$, reflecting the high proportion of films classified as category $0 / 0$ by each reader.

Prevalence of small opacities (based on majority readings) was greater in older than in younger workers, greater in men $(7.4 \%$ with category $0 / 1$ or greater) than in women $(1.3 \%)$, greater in Europeans $(7.3 \%)$ than in Asians $(2.8 \%)$, and greater in smokers $(9 \%)$ than in non-smokers $(1.5 \%)$. Although the prevalence of category $0 / 1$ or greater at the mills ranged from 4 to $13 \%$ for these readers, these differences did not correspond to average differences in dust concentrations between mills. No obvious relation was seen between prevalence of small opacities category $0 / 1$ or more and dust concentration or time worked in current job or with time in industry. If anything, an inverse relation was apparent with dust concentration (fig 2). An apparent inverse relation was also seen for workers with category $1 / 1$ or more.

The shape of small opacities (rounded or irregular according to the ILO classification ${ }^{11}$ ) was also assessed by the readers. Small irregular opacities (SIO) were more commonly seen (19 cases) than small rounded opacities ( 8 cases), 10 being ambiguous. No strongly suggestive relations with other factors were found, including cumulative exposure to dust in the current job.

\section{LUNG FUNCTION}

The lung function of 610 people was investigated in three major subgroups, 286 European men, 145 European women, and 179 Asian men. Only 24 were not included in these subgroups. These were two Asian women and 22 men and women of West Indian origin. As these groups are too small for detailed analysis, their data are not further described. Data from 19 Asian men were missing for one or more

Table 1 Mean anthropometric and occupational data for main population subgroups (SD in parentheses)

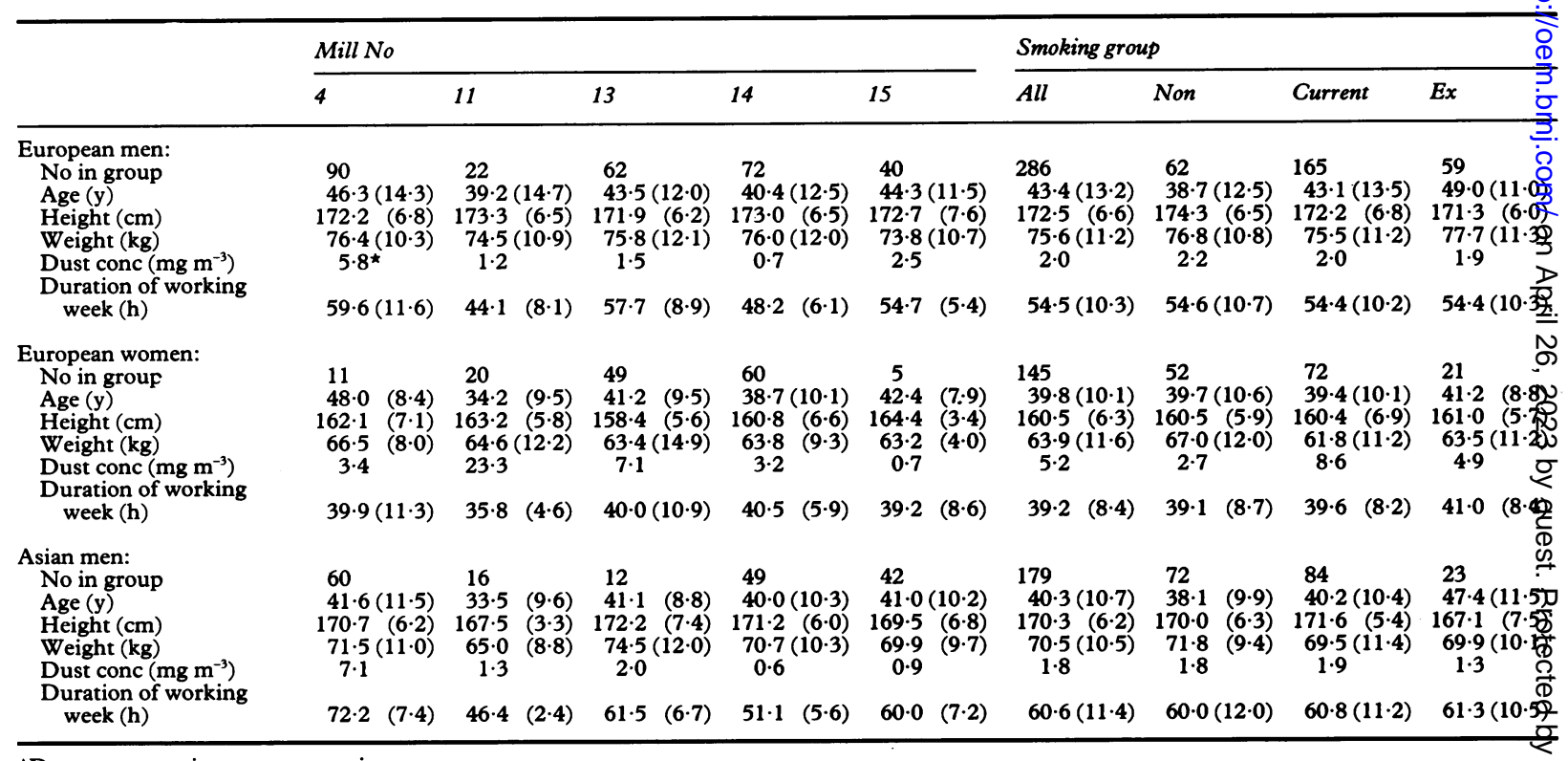

^Dust concentrations are geometric means. 
Table 2 Coefficients from regression equations of indices of lung function

\begin{tabular}{|c|c|c|c|c|c|c|c|c|c|c|c|c|c|}
\hline \multirow{2}{*}{$\begin{array}{l}\text { Index of } \\
\text { lung function }\end{array}$} & \multicolumn{3}{|c|}{ Intercepts for smoking groups } & \multicolumn{3}{|c|}{ Age slopes for smoking groups } & \multirow{2}{*}{$\begin{array}{l}\text { Height } \\
(\mathrm{cm})\end{array}$} & \multirow{2}{*}{$\begin{array}{l}\text { Weight } \\
\text { (kg) }\end{array}$} & \multicolumn{4}{|l|}{ Mill No } & \multirow{2}{*}{$\begin{array}{l}\text { Log } \\
\text { dust conc }\end{array}$} \\
\hline & Non & Current & $E x$ & Non & Current & $E x$ & & & 11 & 13 & 14 & 15 & \\
\hline \multicolumn{14}{|l|}{ European men: } \\
\hline $\begin{array}{l}\text { FEV }_{1}(1) \\
\text { FVC (1) } \\
\text { FEV, FVC }\end{array}$ & $\begin{array}{l}-1.975 \\
-5.661\end{array}$ & $\begin{array}{l}-2 \cdot 012 \\
-5 \cdot 299\end{array}$ & $\begin{array}{l}-2 \cdot 026 \\
-5 \cdot 152\end{array}$ & $\begin{array}{l}-0.039^{\star} \\
-0.026^{\star}\end{array}$ & $\begin{array}{l}-0.043 \\
-0.034\end{array}$ & $\begin{array}{l}-0.042 \\
-0.036\end{array}$ & $\begin{array}{l}0.041^{\star} \\
0.066^{\star}\end{array}$ & $\begin{array}{l}0.005 \\
0.002\end{array}$ & $\begin{array}{l}-0.056 \\
-0.164\end{array}$ & $\begin{array}{r}0.050 \\
-0.036\end{array}$ & $\begin{array}{l}-0.096 \\
-0.165\end{array}$ & $\begin{array}{l}0 \cdot 184 \\
0 \cdot 209\end{array}$ & $\begin{array}{l}0.008 \\
0.004\end{array}$ \\
\hline $\begin{array}{l}\text { TLCO } \\
\text { TLl min }\end{array}$ & $118 \cdot 284$ & $115 \cdot 313$ & $112 \cdot 789$ & $-0.372^{\star}$ & -0.433 & -0.344 & $-0 \cdot 177$ & 0.071 & 1.359 & $2 \cdot 287$ & 1.453 & 1.323 & $0 \cdot 102$ \\
\hline $\mathbf{m m} \mathbf{H g}^{-1}$ ) & $7 \cdot 626$ & $7 \cdot 317$ & $13 \cdot 820$ & $-0 \cdot 200^{\star}$ & $-0 \cdot 291^{\star}$ & -0.335 & $-0 \cdot 164^{\star}$ & $0.086^{\star}$ & 1.085 & 0.574 & -0.598 & -0.301 & -0.075 \\
\hline \multicolumn{14}{|l|}{ European women: } \\
\hline $\begin{array}{l}\text { FEV }_{1}(1) \\
\text { FVC (1) } \\
\text { FEV }_{1} / \text { FVC }\end{array}$ & $\begin{array}{l}-0 \cdot 106 \\
-2 \cdot 766\end{array}$ & $\begin{array}{r}0 \cdot 103 \\
-2 \cdot 237\end{array}$ & $\begin{array}{r}0.185 \\
-2.904\end{array}$ & $\begin{array}{l}-0.024^{\star} \\
-0.016^{\star}\end{array}$ & $\begin{array}{l}-0.033^{\star} \\
-0.031\end{array}$ & $\begin{array}{l}-0.019 \\
-0.010\end{array}$ & $\begin{array}{l}0.026^{\star} \\
0.046^{\star}\end{array}$ & $\begin{array}{l}-0.001 \\
-0.006\end{array}$ & $\begin{array}{l}-0.392^{\star} \\
-0.394\end{array}$ & $\begin{array}{r}-0.150 \\
0.009\end{array}$ & $\begin{array}{l}-0.278^{\star} \\
-0.139\end{array}$ & $\begin{array}{l}-0.117 \\
-0.082\end{array}$ & $\begin{array}{r}-0.011 \\
0.022\end{array}$ \\
\hline TLCO(ml min & 135.665 & $130 \cdot 803$ & $148 \cdot 267$ & $-0.331^{\star}$ & -0.285 & -0.654 & $-0 \cdot 273^{\star}$ & $0 \cdot 115$ & $-2 \cdot 754$ & $-4.914^{\star}$ & $-5 \cdot 043^{\star}$ & -1.786 & $-0.784^{\star}$ \\
\hline $\left.\mathrm{mm} \mathrm{H} \mathrm{g}^{-1}\right)$ & 3.830 & $5 \cdot 186$ & $5 \cdot 626$ & -0.078 & $-0 \cdot 203^{\star}$ & $-0 \cdot 163$ & $-0 \cdot 121^{\star}$ & $-0.082^{\star}$ & 1.086 & 0.555 & 0.699 & $-2 \cdot 284$ & $0 \cdot 124$ \\
\hline \multirow{4}{*}{ 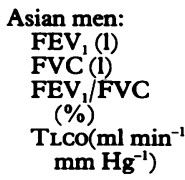 } & & & & & & & & & & & & & \\
\hline & $\begin{array}{l}-2 \cdot 645 \\
-5 \cdot 325\end{array}$ & $\begin{array}{l}-1.919 \\
-4.732\end{array}$ & $\begin{array}{l}-1.738 \\
-4.980\end{array}$ & $\begin{array}{l}-0.010 \\
-0.007\end{array}$ & $\begin{array}{l}-0.031^{\star} \\
-0.024^{\star}\end{array}$ & $\begin{array}{l}-0.036^{\star} \\
-0.020\end{array}$ & $\begin{array}{l}0.037^{\star} \\
0.058^{\star}\end{array}$ & $\begin{array}{l}-0.001 \\
-0.004\end{array}$ & $\begin{array}{l}0 \cdot 128 \\
0.137\end{array}$ & $\begin{array}{r}-0.022 \\
0.140\end{array}$ & $\begin{array}{l}-0.071 \\
-0.279\end{array}$ & $\begin{array}{l}-0.050 \\
-0.131\end{array}$ & $\begin{array}{l}-0.062 \\
-0.091\end{array}$ \\
\hline & 218.820 & $128 \cdot 297$ & $139 \cdot 801$ & $-0 \cdot 111$ & $-0 \cdot 284$ & $-0.542^{\star}$ & $-0 \cdot 263^{\star}$ & 0.064 & 1.025 & $2 \cdot 426$ & 4.457 & $4 \cdot 503$ & 0.333 \\
\hline & $-5 \cdot 405$ & -3.925 & $-5 \cdot 630$ & -0.078 & $-0 \cdot 174$ & $-0 \cdot 102$ & $0 \cdot 172^{\star}$ & $0 \cdot 173 \star$ & $-1 \cdot 197$ & $-2 \cdot 394$ & -1.663 & $-2 \cdot 461$ & 0.693 \\
\hline
\end{tabular}

$~^{*} t>2.0(p<0.05)$. Age slopes for current and ex-smokers are indicated $\star$ if they differ significantly from those for non-smokers. Coefficients for mills are indicated ${ }^{\star}$ when they are significantly different from mill 4 but when they differ significantly from one another this is indicated in the text.

To calculate lung function values for an individual worker, for example, FEV $/$ FVC ratio of a non-smoking European woman from mill 4 , aged 40,160 $\mathrm{cm}$ tall, and exposed to $25 \mathrm{mg} / \mathrm{m}^{-3}$ dust, $\mathrm{FEV}_{1} / \mathrm{FVC}=135.665-(0.331 \times 40)-(0.273 \times 160)-\left(0.784 \times \log _{\mathrm{e}} 25\right)=76.2 \%$. For workers in other categories (sex, smoking, and mill) the appropriate coefficient should be applied including the mill coefficient (mill 4 is zero).

spirometric indices, mainly because of language difficulties, and a further 331 men have been excluded from analyses of TLCo for similar reasons.

Table 1 gives details of anthropometric and other data according to mill and smoking habit. Few women and Asian men (less than 20 subjects) worked at some mills. Considerable differences occurred between groups in the average number of hours worked each week and in mean dust concentration at each mill, reflecting an association between sex, ethnic origin, and occupation. Some jobs associated with high dust concentrations are carried out almost exclusively either by men or by women. On average women worked fewer hours each week than the men and Asian men overall worked six hours a week longer than European men.

By contrast with the other subgroups female smokers experienced much higher dust concentrations $\left(8.6 \mathrm{mg} \mathrm{m}^{-3}\right.$ on average) than female nonsmokers $\left(2.7 \mathrm{mg} \mathrm{m}^{-3}\right)$. This strong association between smoking habit and dust concentration makes it difficult to distinguish any effects of dust from those of smoking in this subgroup. Dust concentrations for Asian men were on average similar to those of European men at each mill but concentrations at mills 11 and 13 showed particularly large differences between men and women.

The average values for lung function are close to predicted normal values ${ }^{13}$ (not shown). No major differences were found between mills but female smokers tended to have lower $\mathrm{FEV}_{1}, \mathrm{FEV}_{1} / \mathrm{FVC}$ ratio, and TLCo than non-smokers and Asian exsmokers had lower FEV 1 and FVC than the other smoking groups, probably because of greater age and shorter stature (table 1).

The results of a stepwise regression analysis of lung function from each subgroup are presented briefly here, and are available in greater detail elsewhere. ${ }^{14}$ After allowing for age, height, and weight, smokers tended to show greater losses of lung function with age, although this was statistically significant only for Asian men (table 2). Differences in lung function between mills were apparent after adjusting for other factors, although these did not correspond to differences between mills in average dust concentrations.

After allowing for these factors, $\mathrm{FEV}_{1} / \mathrm{FVC}$ ratio among European women was found to be inversely related to dust concentration in current job. The estimated effect on the logarithmic scale predicted an $\mathrm{FEV}_{1} / \mathrm{FVC}$ ratio of $78.7 \%$ in a 40 year old nonsmoking woman $160 \mathrm{~cm}$ tall and not exposed to dust at mill 4 , a ratio of $76.9 \%$ in a similar woman exposed to $10 \mathrm{mg} / \mathrm{m}^{3}$ inspirable dust, and a ratio of $76.2 \%$ in a woman exposed to $25 \mathrm{mg} / \mathrm{m}^{3}$ of inspirable dust $(15 \%$ of the workforce experienced exposures higher than this). Table 3 describes the associated losses more fully. The $\mathrm{FEV}_{1}$ of these women was negatively related to dust concentration (estimates of $\mathrm{FEV}_{1}$ corresponding to the examples above are 3.0941 , 
Table 3 Estimated loss of FEV $/ F V C$ ratio ${ }^{\star}$ in European women associated with exposure to selected inspirable dust concentrations (logarithmic relation)

\begin{tabular}{lllllll}
\hline & \multicolumn{6}{c}{ Dust concentration $\left(\mathrm{mg} \mathrm{m}^{-3}\right)$} \\
\cline { 2 - 7 } & 1 & 5 & 10 & 20 & 25 & 50 \\
\hline \begin{tabular}{l} 
Loss of $_{\text {FEV }_{1} / \text { FVC }(\%)}$ \\
\hline
\end{tabular} & 0 & 1.26 & 1.81 & 2.35 & 2.52 & 3.07 \\
\hline
\end{tabular}

* Relative to someone exposed to a dust concentration of $1 \mathrm{mg} \mathrm{m}^{-3}$.

$3.069 \mathrm{l}$, and 3.059 1 respectively), but this relation could easily have arisen by chance; FVC and TLCo were positively related to dust concentration but the relation was not statistically significant.

In other groups, lung function was not related to dust concentration at the conventional $5 \%$ level of statistical significance, and the coefficients were often positive. A negative association between FVC in Asian men and logarithmic dust concentration was statistically significant at the $10 \%$ level. This estimated effect predicted an FVC of 3.675 1 in a 40 year old non-smoking man $170 \mathrm{~cm}$ tall not exposed to dust at mill 4 and FVCs of 3.465 1 and 3.3821 in a similar man exposed to 10 and $25 \mathrm{mg} \mathrm{m}^{-3}$ of inspirable dust respectively. No clear evidence was found that effects of dust were more or less pronounced in younger compared with older subjects. In European men $\mathrm{FEV}_{1}$ and $\mathrm{FEV}_{1} / \mathrm{FVC}$ were associated with only one occupational factor, number of hours worked per week, increasing by $9 \mathrm{ml}$ and $0.23 \%$ per hour worked. No associations were found between lung function and cumulative dust exposure in current job.

LUNG FUNCTION IN SPECIAL GROUPS

Wool textile workers with abnormal lung function

Data on $F E V_{1}$ from the three principal subgroups were used to define the predicted values adjusted for age and height for the members of the subgroup. We have selected those subjects whose lung function was two or more standard deviations below predicted values and have compared them with the rest of the population (table 4). In European men and women these unusual subjects tended to be older and dust concentration in current jobs also tended to be lower than other subjects. These unusual subjects had worked similar or slightly longer times in their current jobs than others. Unusual Asian men showed the inverse relation being younger, experiencing greater dust concentrations, and having spent less time in current job. No clear conclusions could be drawn about the relations between work and unusual lung function.

Overall nine out of $19(47 \%)$ with unusual FEV were current smokers, a slightly lower proportion than within the normal group $(53 \%)$. Eight out of the 18 abnormal subjects ( $44 \%$ ) who had skin prick tests were atopic compared with only $23 \%$ of the remainder. The unusual group worked in only three of the mills, nine at mill 4, and five each at mills 13 and 14, but were distributed evenly between different occupational groups.

\section{Dyers and scourers}

During the course of the analysis of respiratory symptoms in wool textile workers reported previously $^{1}$ it was apparent that the occupational group (consisting of mostly European men) in the essentially wet processes of dyeing and scouring, experienced an increased risk of taking time off work because of chest illnesses. The unadjusted lung function measurements indicated that an unusually high proportion of this group had lower than expected $\mathrm{FEV}_{1}$ when judged by conventional clinical standards.

We therefore investigated further this occupational group, who were exposed to dust concentrations not greater than $4.4 \mathrm{mg} \mathrm{m}^{-3}$. Thirty one workers (28 European men, one European woman, two Asian men) in the group had attended for survey; we have examined the possible effect of working in

Table 4 Characteristics (mean (SEM)) of 19 men and women whose FEV, was more than two residual standard deviations below the predicted normal for their group (unusual). Characteristics for the rest of the population are also shown (others)

\begin{tabular}{|c|c|c|c|c|c|c|}
\hline & \multicolumn{2}{|l|}{ European men } & \multicolumn{2}{|c|}{ European women } & \multicolumn{2}{|l|}{ Asian men } \\
\hline & Unusual & Others & Unusual & Others & Unusual & Others \\
\hline $\begin{array}{l}\text { No } \\
\text { Smokers }(\%) \\
\text { Age }(\mathrm{y}) \\
\text { Height (cm) } \\
\text { Weight }(\mathrm{kg}) \\
\text { Hours worked/week } \\
\text { Years in current job } \\
\text { Log dust conc } \\
\text { FEV }(1) \\
\text { FVC }(1) \\
\text { FEV } / \text { FVC (\%) } \\
\text { TLCo }\left(\mathrm{ml} \mathrm{min}^{-1} \mathrm{~mm} \mathrm{Hg}^{-1}\right)\end{array}$ & $\begin{array}{c}9 \\
67 \\
49 \cdot 7(5 \cdot 1) \\
174 \cdot 8(2 \cdot 5) \\
81 \cdot 1(4 \cdot 9) \\
54 \cdot 5(5 \cdot 2) \\
7 \cdot 8(2 \cdot 1) \\
0.66(0 \cdot 27) \\
1 \cdot 80(0 \cdot 28) \\
3 \cdot 52(0 \cdot 35) \\
51 \cdot 1 \quad(5 \cdot 6) \\
26 \cdot 8(3 \cdot 6)\end{array}$ & $\begin{array}{ll}277 & \\
57 & \\
43.2 & (0.8) \\
172.4 & (0.4) \\
75.5 & (0.7) \\
54.5(0.6) \\
7.7(0.3) \\
0.70(0.08) \\
3.60(0.05) \\
4.83(0.06) \\
74.8(0.6) \\
31.6(0.4)\end{array}$ & $\begin{array}{ll}5 & \\
40 & \\
48 \cdot 3 & (3 \cdot 7) \\
160 \cdot 0 & (5 \cdot 3) \\
60 \cdot 8(3 \cdot 6) \\
39 \cdot 1(4 \cdot 8) \\
10 \cdot 1(3 \cdot 2) \\
0 \cdot 88(0 \cdot 98) \\
1 \cdot 67(0 \cdot 19) \\
2 \cdot 69(0 \cdot 25) \\
62 \cdot 4(4 \cdot 9) \\
21 \cdot 3(2 \cdot 2)\end{array}$ & $\begin{array}{ll}140 & \\
50 & \\
39.5 & (0.9) \\
160.5(0.5) \\
64.0(1.0) \\
39.6(0.7) \\
8.1(0.4) \\
1.68(0.15) \\
2.78(0.04) \\
3.50(0.04) \\
79.6(0.5) \\
24.2(0.4)\end{array}$ & $\begin{array}{cl}5 & \\
20 & \\
34 \cdot 8 & (2 \cdot 1) \\
171 \cdot 6(1 \cdot 6) \\
75 \cdot 0(2 \cdot 5) \\
62 \cdot 4(5 \cdot 1) \\
4 \cdot 4(1 \cdot 2) \\
1.42(0 \cdot 71) \\
2 \cdot 02(0 \cdot 06) \\
3 \cdot 19(0 \cdot 08) \\
63 \cdot 2(1 \cdot 8) \\
33.8(1.9)\end{array}$ & $\begin{array}{cc}174 & \\
48 & \\
40.4 & (0.8) \\
170.3 & (0.5) \\
70.4 & (0.8) \\
60.5 & (0.9) \\
6.4 & (0.3) \\
0.55 & (0.09) \\
3.12 & (0.05) \\
3.90(0.05) \\
80.1 & (0.5) \\
30.2 & (0.4)\end{array}$ \\
\hline
\end{tabular}




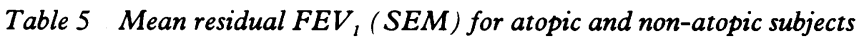

\begin{tabular}{llll}
\hline Group & Atopic subjects & Non-atopic subjects & Approximate $95 \%$ confidence interval $\dagger$ \\
\hline $\begin{array}{l}\text { European } \\
\text { men }\end{array}$ & $-0.154(0.0345)$ & $0.057(0.0379)$ & $(-0.314$ to -0.108$)$ \\
women & $-0.039(0.099)(21)^{\star}$ & $0.009(0.0315)(122)^{\star}$ & $(-0.255$ to 0.159$)$ \\
Asian men & $-0.053(0.082)(41)^{\star}$ & $0.042(0.040)(117)^{\star}$ & $(-0.277$ to 0.087$)$ \\
\hline
\end{tabular}

${ }^{\star}$ Number of subjects in each group.

+Calculated as the difference between estimated regression coefficient $+2 \mathrm{SE}$ of that difference. Where confidence intervals do not contain 0 , the difference between atopic and non-atopic subjects is significant at around $5 \%$ (for example, European men, difference $=$ $-0 \cdot 211 \pm 0 \cdot 103)$.

this occupational group among the 28 European men only.

A further regression model was derived in which an additional (dummy) variable was inserted to separate the effect of being a dyer or scourer from the rest of the study population. The $\mathrm{FEV}_{1}$ was adjusted for age, height, smoking, and hours worked each week (all statistically significant effects). The contribution of interaction terms (of this additional variable) with age, height, smoking, dust concentration, cumulative exposure, and years in current job was also investigated but found to be not significant. After adjustment for the above factors and mill differences, a deficit of $251 \mathrm{ml}$ of $\mathrm{FEV}_{1}$ was found in this occupational group compared with others $(p<$ $0 \cdot 05)$.

\section{ATOPY AND LUNG FUNCTION}

Six hundred and twenty four out of 634 attending for survey agreed to have an intracutaneous prick test performed $(98 \cdot 4 \%)$. One hundred and fifty two $(24.4 \%)$ produced a positive result on the defined criteria, including three to wool extract alone and another nine to wool and at least one other antigen.

As no significant unadjusted lung function differences were found between atopic and non-atopic subjects for the three subgroups, further analysis was carried out by the introduction of atopic or nonatopic state into the best fitting regression model for $\mathrm{FEV}_{1}$, having adjusted for age and physique. Table 5 shows the mean residual FEV ${ }_{1}$ after adjustment for age, height, weight, and smoking habits.

Only among European men was there a statistically significant difference between atopic and non-atopic subjects (confidence intervals do not include zero), atopic subjects having on average an $\mathrm{FEV}_{1} 211 \mathrm{ml}$ lower than non-atopics in this group. The differences within the two other groups, although not statistically significant, were in the same direction. Because dust concentration was only associated with a lung function deficit $\left(\mathrm{FEV}_{1} / \mathrm{FVC}\right.$ ratio) in European women a comparison of the relation between $\mathrm{FEV}_{1} / \mathrm{FVC}$ ratio and log dust concentration in European women who were either atopic or nonatopic was made. This was not able, however, to establish whether there was or was not a significant difference between them, principally because of the small number of atopic subjects (21 in this subgroup).

\section{Discussion}

The study design, a follow up to an original cross sectional study of currently employed workers, leads to the examination of a survivor group of potentially healthier men and women. Because these studies were an initial assessment of the problem, we made no attempt to recruit leavers and we do not know how their exclusion has influenced the results. An attendance rate of nearly $90 \%$ of the currently employed sample at these surveys encourages us to believe that there should not be any major selection bias within the current mill population.

Employees in each sex and ethnic group were exposed to a considerable range of dust concentrations. As a result we do not think that the relation examined will have been biased by any unevenness of distribution of dust concentrations. We were limited by the lack of information on previous dust concentrations, so that cumulative (working lifetime) exposures could not be calculated. Further work would be necessary to make estimates of past exposures to dust. An attempt to provide surrogate information for cumulative exposures was made by exploring the use of an index of cumulative exposure in the current job assuming a constant dust concentration, and taking into account years worked in the job, and this was found to have little apparent influence on lung function or radiographic appearances.

The scarcity of chest radiographic abnormalities among this population and lack of a relation with indices of dust exposure provide no evidence that pulmonary fibrosis or extrinsic allergic alveolitis occur as a result of exposure to wool mill dust. No consistent pattern was found, however, across study groups or indices in the associations between lung function and current dust exposures.

The apparent mildness and inconsistency of the effect shown may indicate that important effects of exposure to wool dust on lung function, if they occur, are rare, or alternatively may be the result of in- 
accuracies in exposure estimates brought about by lack of information on past dust concentrations. Evidence from studies in another industry indicates that inaccuracies in estimates of dust exposures can cause profound underestimates of the influence of exposure on lung function, ${ }^{15}$ and for this reason an attempt to reconstruct histories of exposure in this case may be helpful.

The finding that some lung function indices are positively associated with the number of hours worked each week could indicate some self selection, fitter men working longer hours than less fit men.

These uncertainties contrast with the clearly demonstrated relations between symptoms and current dust concentrations. ${ }^{1}$ Conceivably, important lung functional deficits, if they occur, are more likely to be related to cumulative exposure to dust, while symptoms of rhinitis or chronic bronchitis could be more strongly related to current exposure to dust.

Functional decrements apparently unassociated with exposure to dust were found in the occupational group consisting of dyers and scourers, who use powdered dyestuffs and caustic soda. We are aware of the symptomatic and immunological findings in workers using reactive dyes. ${ }^{16}$ It is not known to what extent reactive dyes had been used by these workers but at least one mill had recently changed to using non-reactive dyes.

We record our thanks to $\operatorname{Dr} A$ Leach, Senior Employment Medical Adviser, Leeds; Drs J Bennett, P O Pern, and A Rickards of British Coal Radiological Services for radiographic readings; Miss J Jeffryes, P A Hutchison, and P P Johnston for radiography, lung function, and skin tests, and Miss A Lobban for preparing the manuscript. Our thanks also go to all the managerial staff and employees of the mills who contributed their time to this study.
This work was carried out with a grant from the Health and Safety Executive.

1 Love RG, Smith TA, Gurr D, Soutar CA, Scarisbrick DA, Seaton A. Respiratory and allergic symptoms in wool textile workers. Br J Ind Med 1988;45:727-41.

2 Allardice JT, Clarke EC, Jones RD. A study of the prevalence of epistaxis and respiratory symptoms in carpet backwinders. $J$ Soc Occup Med 1983;33:36-41.

3 Brysiewicz K, Buluk H, Cesarz-Fronczyk M, et al. The effects of work in dusty surroundings on the prevalence of chronic bronchitis among the workmen of Sierzon's establishments of the wool industry at Bialystok. Gruzlica 1970;38:657-61.

4 Jordeczka S, Basa S, Basa B. Presence of chronic non-specific bronchopulmonary disease in wool industry workmen. Gruzlica 1970;38:643-50.

5 Mathur KC, Misra SN. Incidence of pulmonary disease among wool workers. Indian Journal of Chest Diseases 1972;14:172-8.

6 Zuskin JH, Valic F, Bouhuys A. Effect of wool dust on respiratory function. Am Rev Respir Dis 1976;114:705-9.

7 Ozesmi M, Aslan H, Hillerdal G, Rylander R, Özesmi C, Baris YI. Byssinosis in carpet weavers exposed to wool contaminated with endotoxin. $\mathrm{Br} J$ Ind $\mathrm{Med}$ 1987;44:479-83.

8 Jones CO, Dodgson J, Smith TA, Thorpe HL. Epidemiological studies in West Yorkshire wool textile mills. Inspirable dust exposures of wool textile workers. Ann Occup Hyg (to be published).

9 Meade F, Saunders MJ, Hyett F, Reynolds JA, Pearl N, Cotes $\mathrm{JE}$. Automatic measurement of lung function. Lancet 1965;ii:573-5.

10 Copland L, Burns J, Jacobsen M. Classification of chest radiographs for epidemiological purposes by people not experienced in the radiology of pneumoconiosis. Br J Ind Med 1981;38:254-61.

11 International Labour Office. Guidelines for the use of ILO international classification of radiographs of pneumoconiosis. Geneva: ILO, 1980. (ILO Occupational Safety and Health Series No 22 (rev 89).)

12 Dixon WJ, Brown MB, Engelman L, et al, eds. BMDP statistical software. Berkeley: University of California Press, 1983.

13 Quanjer P, ed. Standardised lung function testing. Report of a working party. Luxembourg: Commission of the European Communities, 1983.

14 Love RG, Donaldson K, Cullen RT, et al. Further studies of respiratory health of wool textile workers. Edinburgh: Institute of Occupational Medicine, 1988. (IOM Report TM $/ 88 / 16$.)

15 Heederick D, Miller BG. Weak associations in occupational epidemiology: adjustment for exposure estimation error. Int $J$ Epidemiol 1988;17:970-4.

16 Docker A, Wattie JM, Topping MD, et al. Clinical and immunological investigations of respiratory disease in workers using reactive dyes. $\mathrm{Br} J$ Ind Med 1987;44:534-41.

Accepted 1 October 1990 